\title{
Tysk skønlitteratur i Danmark
}

\section{Udsnit af en udviklingshistorie fra 1980'erne til i dag}

\begin{abstract}
Med afsat $i$ iser forlaget Gyldendals katalog af tyske udgivelser, giver artiklen et forsøg på et indblik i den tyske litteraturs plads i den danske offentlighed i den sidste generations tid.
\end{abstract}

af cand.mag. Louise Holm

I 2013 udgav Goetheinstituttet i Danmark sammen med Forlaget Vandkunsten bogen Begyndelser, Nye tyske boger på dansk 2010-2013. 10.000 gratis eksemplarer af bogen blev uddelt på biblioteker, på uddannelsesinstitutioner og $\mathrm{i}$ andre offentlige rum. Dette var et udspil for at promovere de 31 skønlitterære titler fra tysksprogede samtidsforfattere, som blev udgivet i dansk oversættelse i løbet af de tre år. Navne som Herta Müller, Christa Wolf, Clemens Meyer, Ferdinand von Schirach og Judith Schalansky samt mange flere i Danmark mere eller mindre kendte forfattere fik plads, tillige gjorde deres danske oversættere.

Gratisudgivelsen var en reaktion på en tendens, som har været præsent i mange årtier: Den danske offentlighed kender ikke til størstedelen af den tysksprogede litteratur, og der udgives ikke mange tyske bøger oversat til dansk.

Ved at se på UNESCOs Index Translationum, ${ }^{1}$ som kategoriserer oversat litteratur verden over, tydeliggøres det, at tysk oversat litteratur har haft det langt sværere i Danmark end f.eks. oversættelser fra engelsk.

På en uofficiel liste, Goetheinstituttet har samlet af tyske udgivelser på Det Kongelige Bibliotek, opregnes i perioden
1976-2004 kun 481 skønlitterære tyske udgivelser danske forlag.

På konferencen Tysk nu(!) i oktober 2009 udtalte Johannes Riis, litterær direktør for Gyldendal, at der ikke findes et stort nok publikum til, at det er rentabelt at udgive så megen tysk litteratur, som forlaget selv kunne ønske, ${ }^{2}$ og ifølge Rasmus Axelsen fra agenturet Leonhardt \& Høier har tysk litteratur i Danmark specielt fået det svært efter Danmarks besættelse pga. de negativt prægede stereotyper forbundet med Tyskland. ${ }^{3}$

I Sverige ses en lignende tendens til, at kun et fåtal af bøger oversættes fra tysk og udgives. Ph.d.-stipendiat Fredrik Agell fra Stockholm Universitet skriver i 2013, at den generelle fordom fra læsernes side er, at tysk skønlitteratur er for svær, hvorfor forlagene har sværere ved at sælge tyske titler end titler fra andre sprog. ${ }^{4}$ Selv med store børnebogsforfattere som Michael Ende og Angela Sommer-Bodenburg samt opsving under Ostalgie-bølgen, ${ }^{5}$ den udbredte poplitteratur og de mange nye kvindelige forfattere i 1990'erne, der blev kategoriseret under das Fräuleinwunder, bliver dette tunge billede af litteraturen bibeholdt.

Billedet har indtil videre været, at de i Skandinavien allerede etablerede 


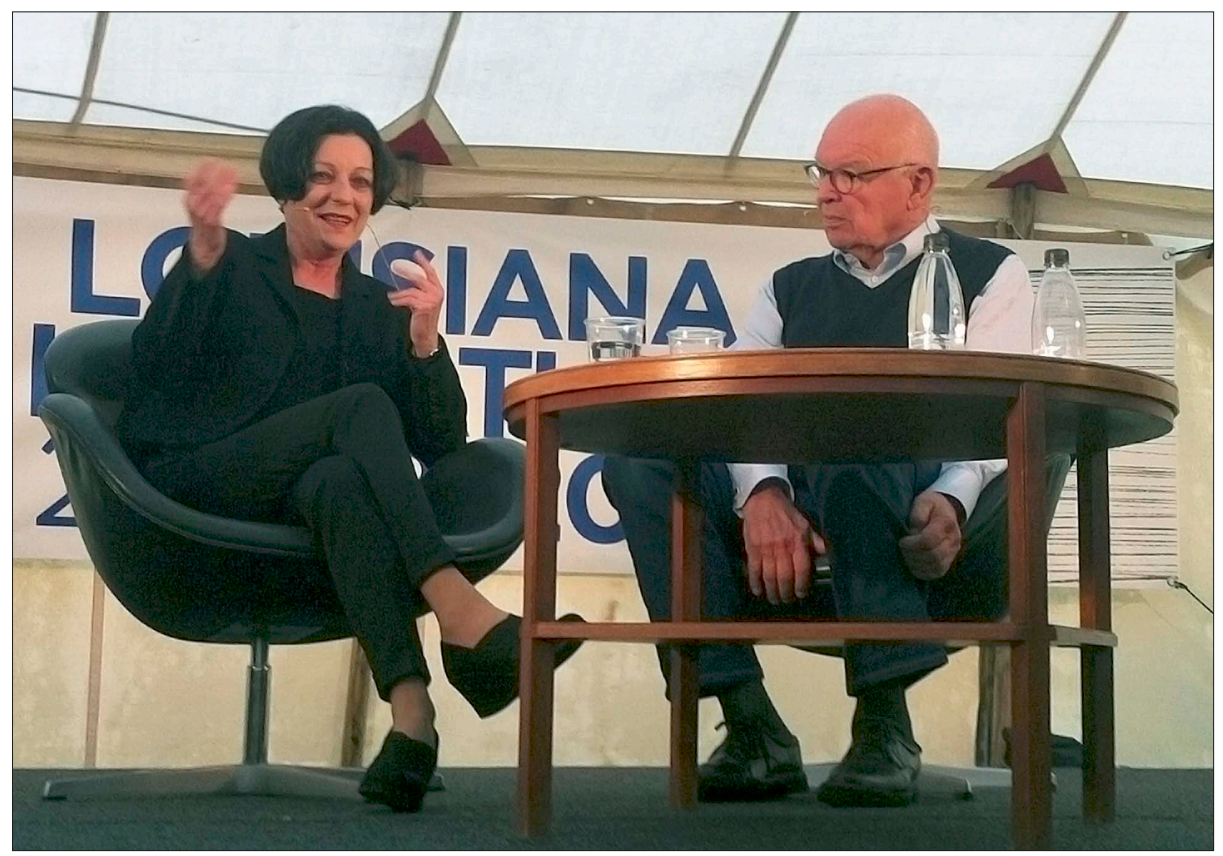

Herta Müller i samtale med Niels Barfoed på Louisiana Literature 2014. Foto ved forfatteren.

forfatterskaber (f.eks. Günter Grass) kan udgives uden store problemer, hvorimod de fleste forlag tøver med at satse på debuttanter og endnu ikke oversatte tyske forfatterskaber.

I denne artikel fokuseres på nogle af de forfatterskaber, der er blevet valgt til udgivelse samt på tendenserne for de udgivne bøger fra 1980'erne og frem. Udgangspunktet for den beskrevne litteratur er her Gyldendal, da dette forlag, fordi det er Danmarks største og ældste, ofte som det første har haft muligheden for gennem tiden at vælge mange af de tyske forfattere til eller fra. Der findes i stort antal anmeldelser af en del af de udgivne forfattere, og disse giver en indikation om, hvorfor der stadig skulle eksistere en idé om tysk litteratur 'svær', 'tung' eller utilgængelig.

\section{Mellem børs og katedral}

Inden forfatterne introduceres, må et modsætningsforhold nævnes, som i forlagets historie har været en faktor i udvælgelsen af bøger.

Samtidig med at et privat forlag er en virksomhed, der er præget af et marked og påvirket af økonomi, er det ligeledes en kulturinstitution, som oftest er båret af en kulturel idealisme. ${ }^{6}$ Det fremgår f.eks. af Gyldendals årsrapport fra 2014, at forlaget har en selvudnævint forpligtelse til at stimulere læsning gennem en mangfoldig udgivelsespolitik.?

Koncernen har i sin målsætning egne kulturelle forventninger om en æstetisk værdi. Altså en idé om at have et kulturelt ansvar for læseren. Samtidig med at forlaget lægger vægt på den 'kulturidea- 
listiske' litteratur, hvis primære fokus er bøger, både smalle og brede, af litterær høj kvalitet, tænker Gyldendal dog også på sig selv som en forretning, der skal give overskud. ${ }^{8}$

I programmet Sommergasten på P1 den 1. august 2013 udtalte Gyldendals direktør Stig Andersen således, at man i forlagsbranchen befinder sig i spændet mellem "børs og katedral", altså mellem marked og æxtetisk ideologi. ${ }^{9}$ De oversatte bøgers udvælgelse sker på baggrund af overvejelser i dette spænd.

Hvilket af de to yderpunkter, der lægges mest vægt på, ændrer sig dog i løbet af tid og fra forlag til forlag. På Gyldendals skønlitterære afdeling for oversættelser vises eksempler på, hvordan man er gået fra at have et primært fokus på litterær kvalitet og ikke i lige så høj grad på markedet til det omvendte. Den litterære kvalitet må naturligvis stadig være i orden, men ses desuden ud fra et salgsperspektiv. Derfor er marketingafdelingen i Gyldendal også blevet en meget større samarbejdspartner for den skønlitterære afdeling efter år 2000, end den var det førhen.

Indtil midten af 1990'erne ser man i den skønlitterære afdeling for oversat litteratur derfor overvejende et andet ræsonnement end kun det, at de udgivne bøger skulle have formodet publikumsinteresse. Her er en stor del af tanken i høj grad, at man med bøgerne potentielt kan danne sin læser. Derfor udgives en stor del litteratur fra tysk med et højt lixtal, samt litteratur som stiller samfundsmæssige problemer under debat.

\section{Den samfundskritiske forfatterstemme}

For den danske presse i 1980'erne og 90'erne er tysk litteratur og politik, måske blandt andet som følge heraf, ofte ikke til at skille ad. I pressematerialet fra denne periode findes utallige eksempler herpå, som dette citat fra Berlingske Tidende om en samtale mellem forfatterne Ingo Schulze og nyligt afdøde Günter Grass på Louisiana i 1999: "Og at Günter Grass er langt den kendteste skyldes ikke nødvendigvis at Ingo Schulze er et mindre talent. [...] Endnu engang fik man bevis for, at tysk litteratur sjeldent kan diskuteres, uden at det lige så meget kommer til at handle om tysk politik og tysk historie." (Søren Kassebeer i Berlingske Tidende 2.9.1999).

I 2003 udkom Roy Langers i tyskdanske kredse kendte og ofte benyttede doktordisputats Die Darstellung Deutschlands in Dänischen Medien ("Fremstillingen af Tyskland i danske medier"). Elin Fredsted, som tilbage i $1985 \mathrm{skrev}$ om danske interviews med vesttyske forfattere, citeres for, at man i interviews lavet af danske journalister ofte kan spore en hensigt fra journalistens side, om at ville fremprovokere en kritik af Forbundsrepublikken fra forfatteren. ${ }^{10}$

Hvis man ser nærmere på pressemateriale fra 1980 'erne, opdager man, at samfundskritikere får megen taletid - f.eks. nobelpristagerne Heinrich Böll, Günter Grass og Siegfried Lenz og østtyskerne Christoph Hein og Christa Wolf. Disse forfattere arbejder på hver deres måde med Tysklands problematiske fortid og samtid.

I de danske medier er man for det meste positivt indstillet overfor forfatternes kritik, og selvom der findes en del polemik om f.eks. Grass og Wolf i Tyskland, forsvarer de fleste danske aviser i 1980'erne og 90'erne begge forfattere imod den tyske offentlighed. Forfatterne bliver i høj grad positioneret som eksper- 


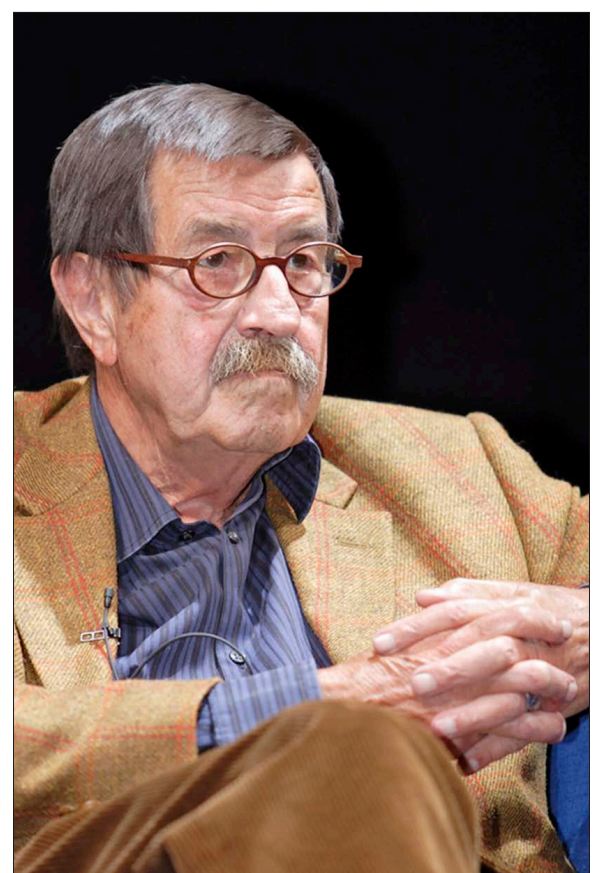

Günter Grass til bogpremiere på Når løget skrælles 2006. Foto: Wikimedia Commons.

ter, som står udenfor det tyske samfund og kan sætte fingeren på dets problemer, som de to følgende citater viser.

"Grunden til den store ståhej var, at Günter Grass mindede den kollektive tyske hukommelse om tiden fra Tysklands samling 1871 til 1945, og denne dystre fortid lod han fortsætte som efterdønninger helt frem til i dag. Det var utilgiveligt for den litterære og politiske offentlighed. Det passede dem ikke, at den tyske historie skulle diskuteres, fordi den gamle historie derved netop ville blive en længere historie" (Berlingske Tidende 19.4.1996).

"Christa Wolf er en af Europas stærkeste samfundskritikere og en af denne verdensdels bedste forfattere. [...] Der er tilbageblik til Hitler-årene, der er udsyn og profetier. (Ingolf Thomsen i Dagbladet
Holstebro, Fyns Amts Avis og Ringkøbing Amts Dagblad 11.9.1990).

Som tysk forfatter i Danmark var specielt Günter Grass et stort navn. Ligesom Danmarks Rifbjerg var han aldrig bleg for at blande kunsten med den samfundsmæssige debat. Bearbejdelsen af arven efter Det tredje Rige, opbygningen af det tyske samfund op igennem anden halvdel af det tyvende århundrede og murens fald blev behandlet. Også i Danmark blandede Grass sig flere gange i politiske diskussioner. Han havde f.eks. en fejde med Bertel Haarder i Information, da han kaldte dansk politik for racistisk, ligesom Jyllands-Posten fik det glatte lag af ham efter publiceringen af Muhammedtegningerne. ${ }^{11}$

På Gyldendal var man på dus med ham, og hans oversætter, Per Øhrgaard, en personlig ven. Man udgav i løbet af årene næsten alle Grass' bøger med undtagelse af et par. For forlaget var han et af de vigtigste tyske navne i den skønlitterære afdeling for oversat litteratur.

\section{Oversete litterære eksperimenter?}

I 2005 udkom Opmålingen af Verden, som blev årets store tyske bestseller. Forfatteren bag, Daniel Kehlmann, blev i 2008 interviewet til det litterære internetmagasin LitteraturNu og udtalte da: "For at være lidt polemisk, så er det meste af den tyske efterkrigslitteratur så kedelig og livløs, at selv de tyske læsere er kommet til at hade den. Forfattere som f.eks. Heinrich Böll og Günter Grass - hvis første par fantasifulde romaner, jeg ellers elsker - kom til i adskillelige årtier at dominere den tyske litterære scene med politiseret og humorforladt socialrealisme. Man var så optaget af efterkrigsskyld og -traumer, at man totalt overså de spændende lit- 
terære eksperimenter, der foregik i resten af verden i 1960'erne og-70'erne". ${ }^{12}$

Om man er enig ej i denne udtalelse, lader det til, at man på Gyldendal har holdt fast i en bestemt form for tysk litteratur indtil op i 1990'erne. Udover klassikerne som bl.a. Herman Hesse og Thomas Mann blev nyere forfattere, som man valgte at udgive (f.eks. den unge østtysker Ingo Schulze og den tysksprogede, rumænske Herta Müller) stadig i høj grad læst ind i en samfundskritisk, politisk sammenhæng, samtidig med at deres sproglige særegenheder blev vægtet.

Da man på Gyldendal i 1985 præsenteres for en ny mere letbenet genre, fravælger man således Patrick Süskinds bestseller Das Parfum. Die Geschichte eines Mörders fra det schweiziske forlag Diogenes. Først i 2005, da det bliver kendt, at et tysk-fransk-amerikansk samarbejde om at filmatisere bogen er i gang, udgiver Lindhardt \& Ringhof bogen med den danske titel Parfumen - Historien om en morder.

Gyldendals litterære scout i Berlin 1985 kalder bogen en "højest læsværdig, spændende og på den bedste måde underholdende roman. En genre som ellers er yderst sjældent repræsenteret i det tyske sprogrum."13

Dog er man fra forlagets side tilbageholdende, da man mener, at bogen er for morbid og 'gemacht'. Fokus er her, at bogen ikke er af høj nok litterær kvalitet til, at man vil udgive den. Selvom det også er en overvejelse, tænkes her ikke så meget i salgbarhed og marked, som i kulturel og æstetisk kvalitet.

Tysksprogede oversættelser efter år 2000 I løbet af 1990'erne og efter år 2000 vægtes denne kulturelle kvalitet overfor publikumsinteresse dog anderledes. I langt højere grad bliver fokus lagt på bogens salgbarhed, og generelt i forlagets afdelinger tænkes marked og kvalitet som to ting, der gerne skal spille sammen. En liste over de udgivne navne ud fra agenturet Leonhardt \& Høiers salgsliste viser, at der bl.a. på Gyldendal er blevet plads til en del debutanter, krimier og underholdningsromaner mellem de mere seriøse eller finlitterære udgivelser.

På Gyldendals hjemmeside bliver Robert Löhrs bog Skakautomaten fra 2007 fremhævet som en bog, der "flittigt bliver sammenlignet med Süskinds Parfumen". ${ }^{14}$ Da man i 2011 stod overfor valget om at skulle udgive succesen 3096 Tage af den østrigske Natascha Kampusch, som omhandler forfatteren bortførsel og fangenskab gennem otte år, valgte man at udgive bogen, trods en bekymring om, hvorvidt historien havde været for eksponeret i tabloidpressen, til at kunne bære det. Bogen var af høj nok litterær kvalitet, til at kunne passe ind i forlagets program. Fokus lå samtidig i højere grad end den tidligere nævnte udgivelse på, at bogen ville sælge godt. ${ }^{15}$

En stor del af den udgivne litteratur i løbet af 2000'erne og frem er stadig nyoversatte klassikere af afdøde eller etablerede politiske forfattere som Thomas Mann, Herman Hesse, Günter Grass, Christoph Hein og Hans Magnus Enzensberger, der får en del nye titler oversat. Heroverfor står forfattere som Natascha Kampusch, Leonie Swann, Robert Löhr, Natasa Dragnic, Ferdinand von Schirach og Karen Duve, der alle inden for deres forskellige områder (bl.a. krimier, kærlighedsromaner og biografiske historier) står for en anden form for litteratur end den politisk mættede prosa. 
Gitte Zchoch fra Goetheinstituttet i Tyskland fremlægger i en artikel fra $2011^{16}$ hvordan man bevæger sig væk fra tendensen til at ville videreformidle "det sande DDR" eller andre historiske tyske områder, til i højere grad at fokusere på den gode historie - og mindre på de samfundsmæssige omgivelser omkring den. Man bevæger sig ifølge hende væk fra den tunge politiske fortælling, som dog stadig er at finde på de fleste forlag, f.eks DER TURM af Uwe Tellkamp (Suhrkamp, 2008), og man udgiver også lettere stileksperimenter som Timur Vernes Han er tilbage (Tiderne Skifter).

Denne alsidighed og leg med genrer og historien, som de forskellige bøger tilbyder, giver måske også den danske læser et mere alsidigt billede af, hvad tysk litteratur er og kan.

\section{Forlaget står ikke alene}

Hvis man vil kunne udtale sig videre om tysk litteraturs og kulturs stilling $\mathrm{i}$ Danmark generelt, er det vigtigt at holde sig for øje, at tysk kulturformidling sker i en større sammenhæng og ikke alene i forlagsverdenen. Derfor er det oplagt også at fokusere på danske institutioner for tillæringen af det tyske sprog (skoler, universiteter m.v.), samt på politiske beslutninger som har påvirket disse institutioner.

\section{Noter}

Artiklen er en omarbejdelse af mit speciale, Mellem ideologi og marked - Gyldendal som formidler af tysk litteratur i Danmark, der modtog Den danske Germanistforenings specialepris.

1 Ifølge databasen er i alt 4.873 titler fra 1979 til 2012 oversat fra tysk til dansk.
I artiklen behandles forlagsbranchen - isoleret fra et større trans-kulturelt netværk - som udgangspunkt for kulturformidlingen af tysk litteratur. Netværket består af mange andre instanser for udbredelsen af tysk kultur i Danmark såsom Goetheinstituttet og diverse agenturer, biografer og filmfestivaller. Også personlige aktører med målet om et større kendskab til tysk sprog og kultur i Danmark, vidensinstitutioner og erhvervsliv har noget at sige. Forlagsvæsen, medier, videnskabsverdenen og undervisningsinstitutionerne spiller på denne måde sammen.

Når Goetheinstituttet sammen med et forlag som Vandkunsten udsender Begyndelser, og diverse festivaller viser filmatiseringen af romaner som den netop aktuelle Dengang vi dromte af Clemens Meyer, kan dette være med til at skabe et skred væk fra synet på den tyske litteratur som mere tung og alvorlig end f.eks. den engelske.

I en tid hvor tysk sprog ellers er på deroute, hvor færre vælger tysk i gymnasiet og hvor Roskilde Universitet for et par år siden måtte opgive sprogfagene fransk og tysk, kan det tænkes, at man med flere tyske bøger, øget opmærksomhed om disse og større alsidighed i udgivelserne på længere sigt kan skabe en større interesse for vores nabo mod syd.

Til sammenligning er der i samme periode registreret 40.618 titler oversat fra engelsk til dansk, og 3.582 bøger oversat fra fransk til dansk. Fra dansk til tysk er oversættelsen af 2.958 bøger registreret i samme periode. Af de tyske bøger, som blev oversat fra tysk til dansk, er 1.878 registreret mellem 1979 og 1990 og 2.995 registreret 
efter 1990. Tallene herfra er langt fra fyldestgørende, da ikke alle titler er registreret i databasen. Alligevel er dette en god indikator for en sammenligning mellem prioriteringen af oversættelsen af forskellige sprog, samt et ca. antal for hvor mange tyske titler, man kan finde på det danske marked. Tallene er hentet 18.4.2015. $<$ portal.unesco.org/culture/en/ev.php$\mathrm{URL}$ ID $=7810 \& \mathrm{URL} \_\mathrm{DO}=\mathrm{DO}$ TOPIC\&URL_SECTION=201.html $>$.

2 Johannes Riis i M.S. Andersen \& K.S. Jacobsen (m.fl.) (red.) (2010): Tysk nu, Konference om tysk sprog og kultur $i$ offentlighed, forskning og undervisning $i$ Danmark.

3 Interview med Rasmus Axelsen 17.1.2014 på agenturet Leonhardt \& Høier.

4 F. Agell (2013): "Bilden av tysk litteratur som svår hämmer introduktionen i Sverige". I Tidskriften Respons, Recensionstidskrift för humaniora \& sambällsvetenskap Nr.6/2013, s. 12-15.

5 Ostalgie, en spøgende sammenblanding af ordene Ost og Nostalgie, er en betegnelse for den nostalgiske strømning, der er opstået i Tyskland omkring det tidligere DDR. Sehnsucht nach [bestimmten Lebensformen] der DDR <www.duden. de/rechtschreibung/Ostalgie>). Besøgt 30.4.2015.

6 F. Triebel (2004): Theoretische Überlegungen zur Verlagsgeschichte. <www.iasl. uni-muenchen.de/discuss/lisforen/Triebel_Theorie.pdf $>$.

7 "Gyldendals fokus på samfundsansvarlighed omfatter særligt arbejdet med at værne om ytringsfriheden og med at stimulere læsning gennem en mangfoldig udgivelsespolitik båret af kvalitet" (Gyldendals Årsrapport 2014, s. 13).

8 Jævnfør Gyldendals årsrapport 2014.
9 P1 - Sommergesten på P1 (1.08.2013): Forandringens vinde bleser over forlagsbranchen: http://www.dr.dk/arkivP1/ Serier/Sommergaesten_2013/Udsendelser/20130617114018.htm, besøgt $\mathrm{d}$. 30.4 .2015 .

10 "Oft spürt man in Interviews mit deutschen Schriftstellern die Absicht, eine Negative Kritik der Bundesrepublik zu provozieren". R. Langer (2003): Die Darstellung Deutschlands in dänischen Medien, Eine Mediendiskursanalyse, s. 156.

11 J.K. Dreyer: "Grass slipper for tiltale", Information 31.8.2002; K. Olsen: "Grass og Beskyldningerne”, Jyllands-Posten 16.5.1999.

12 Daniel Kehlmann i interview med Anders Gudmundsson, Magi og humor (nu også på tysk) - Interview med Daniel Kehlmann, LitteraturNu, 21.4.2008. http://litteraturnu.dk/magi-og-humor-nu-ogsa-pa-tyskinterview-med-daniel-kehlmann/ . Besøgt 15.4.2015.

13 "[...] ein höchst lesenswerter, spannender und im besten Sinn unterhaltsamer Roman [...]. Ein Genre also, das in deutschen Sprachraum sonst äußerst kärglich vertreten ist - daher wahrscheinlich auch die ungewöhnliche Publizität im Ausland“. Den tyske scout til Gyldendals redaktion 15.2.1985, Gyldendals arkiv.

14 Gyldendal.dk, Skakautomaten, http:// www.gyldendal.dk/skakautomatenid15686. besøgt 1.5.2015.

15 Interview med fhv. redaktør Nanna Lund foretaget 22.11.2013.

16 G. Zschoch (2011): End of the Wenderoman - The GDR as Space for Stories, Fra Goethe.de, oktober 2011. http://www. goethe.de/kue/lit/aug/en8261698.htm, besøgt 15.4.2015. 